\title{
Ismertetés: Az alvás és az aktív kültéri játékkal töltött idő közti kétirányú összefüggés vizsgálata 10-13 évesek körében
}

\author{
Bi-directional association between sleep and outdoor active play \\ among $10-13$ year olds
}

Ismerteti: $\quad$ Máté Zsuzsanna $\square$

SZTE ÁOK Népegészségtani Intézet

Szerzők: Yingyi Lin, Michael M. Borghese, lan Janssen

Megjelenés: BMC Public Health. 2018;18:224. doi: 10.1186/s12889-018-5122-5.

Beküldve: 2018. 04. 12.

doi: $10.24365 /$ ef.v59i3.278

Kulcsszavak: gyermek, fizikai aktivitás, alvás

Keywords: child, physical activity, sleep

\section{BEVEZETÉS}

Bár az alvást és a fizikai aktivitást alapvetően két független magatartási tényezőként kezeljük, a kutatók egyre nagyobb érdeklődéssel tekintenek a közöttük lévő kapcsolat meghatározására. Az eddigi kutatások, amelyek során az alvás és a fizikai aktivitás kapcsolatát vizsgálták iskoláskorú gyermekek és serdülők körében, ellentétes eredményeket szolgáltattak, ami részben abból is adódhat, hogy a fizikai aktivitás lehetséges specifikus típusait nem különítették el a vizsgálatok során. A fizikai aktivitás típusának figyelembevétele azért szükséges, mert a különböző típusok különböző összefüggést mutathatnak az alvással, és ha csupán a teljes (összesített) fizikai aktivitást vesszük figyelembe, ezek az összefüggések rejtve maradhatnak. Példának okául a szervezett sporttevékenységek jellemzően inkább a kora reggeli vagy késő esti órákra esnek, ami negatívan befolyásolhatja az alvást azáltal, hogy kihatással van a reggeli kelés és az esti lefekvés időpontjára. Az aktív kültéri játék (pl. játszótér, labdajátékok, kerti játékok) ezzel szem- ben nem menetrendszerű tevékenység, és olyan jellemzői vannak, melyeknek köszönhetően hozzájárulhat a nyugodt alváshoz. A kutatók annak megválaszolását tűzték ki célul, hogy a vizsgált gyermekek körében fennáll-e kétirányú összefüggés az alvás bizonyos jellemzői, valamint az aktív kültéri játékkal töltött idő között.

\section{MÓDSZEREK}

A vizsgálati mintát az Active Play Study (Az aktív játék vizsgálata) alanyai adták: 2015 januárja és 2016 decembere között 10-13 éves korú gyermekek adatait dolgozták fel, akik a kanadai Kingstonban éltek és jártak iskolába. A vizsgálat során az alábbi adatokat használták fel: 1 . a résztvevők által 7 napon és 8 éjszakán át viselt akcelerométer (aktivitásmérő eszköz) adatait; 2. a szintén azonos ideig viselt, helymeghatározásra alkalmas jeladó karóra adatait; 3. a vizsgálat során vezetett napló adatait, amelyben a résztvevők rögzítették a lefekvés és felkelés időpontját, valamint ha szervezett 
sporttevékenységben vettek részt, ha kinti házimunkát végeztek, vagy ha nem viselték a mérőeszközöket; 4. egy „okoseszközön” a résztvevők és az egyik szülő által kitöltött 20 perces kérdőív adatait; 5. fizikális vizsgálatok (pl. testtömeg, testmagasság) eredményeit; 6. a földrajzi információs rendszer Kingston területére vonatkozó adatait; 7. iskolai elfoglaltság, időtöltés adatait; 8. a napkelte és napnyugta időpontját Kingston városára vonatkozóan. A vizsgálat időtartama alatt minden évszakban azonos számú résztvevőt (összesen 433 főt) vontak be a vizsgálatba.

Az alvás jellemzésére négy tényezőt vizsgáltak: 1. az ágyban töltött időt, azaz a lámpaoltás és a reggeli felkelés között eltelt időt; 2 . az alvás időtartamát, azaz az ágyban töltött időn belül az alvással töltött órák számát/nap; 3. az alvás középidejét, ami a lámpaoltás és a reggeli felkelés között eltelt idő felére esett; 4. az alvás hatékonyságát, azaz az alvás időtartamának és az ágyban töltött időnek a hányadosát (\%-ban megadva).

Az alvás jellemzői és az aktív kültéri játékkal töltött idő összefüggéseinek elemzése az általánosított becslő egyenlet (generalized estimating equation, GEE) modellel történt, amely számos zavaró tényezőt (pl. kor, nem, család jövedelme, környező forgalom, zöldterületek) is figyelembe vett.

\section{EREDMÉNYEK}

Az eredmények alapján szignifikáns összefüggés mutatkozott az aktív kültéri játékkal töltött idő és az azt követő éjjelen az ágyban töltött idő között $(p=0,017)$. Ez azt jelenti, hogy minden 60 perc/nap emelkedés az aktív kültéri játékkal töltött időben éjszakánként 4 perccel növelte az ágyban töltött időt - ami statisztikailag szignifikáns, de klinikailag nem -, míg az alvás időtartama, az alvás időrendje és az alvás hatékonysága nem változott. Ezzel szemben egyik alvási paraméter sem mutatott szignifikáns összefüggést a következő napon aktív kültéri játékkal töltött idővel.

\section{KÖVETKEZTETÉSEK}

A jelen vizsgálat és korábbi kutatások arra utalnak, hogy az aktív kültéri játékkal töltött idő befolyásolása valószínűleg nem gyakorolna jelentős hatást az alvásra, hacsak az intervenciók nem eredményeznének több órányi változást a játékidőben, ami kétséges. Fontos megjegyezni, hogy a jelen vizsgálatban a gyermekek alvási ideje és alvásminősége rendkívül jó volt, így ennek köszönhetően lehetséges, hogy az alvási magatartásban nem is lehetett további javulást elérni az aktív kültéri játékkal töltött idő növelésével.

\section{TANULSÁGOK A HAZAI SZAKEMBEREK SZÁMÁRA}

Az alvással kapcsolatos egyes jellemzők és az aktív kültéri játékkal töltött idő közötti időbeli és kétirányú összefüggés vizsgálata során egyedül a nap folyamán aktív kültéri játékkal töltött idő mutatott szignifikáns összefüggést az alvási jellemzőkkel. Ennek kapcsán kiemelendő, hogy az az általános feltételezés, miszerint a kültéri játékkal töltött idő elősegíti a jó alvást, nem feltétlenül igaz. Figyelembe véve a zavaró tényezőket pl. hogy a vizsgálat résztvevői közül senkinél sem fordult elő diagnosztizált alvási rendellenesség, vagy hogy nem történt poliszomnográfiás vizsgálat (többféle élettani folyamat követése alvás alatt)-, valamint hogy a vizsgálati csoport 10 - 13 éves korú gyermekekre korlátozódott, szükség van további, a fizikai aktivitás és az alvás közötti kapcsolatot vizsgáló kutatásokra. Ezen további kutatások során nagy hangsúlyt kell fektetni a modern mérőeszközök használatára, amelyek lehetővé teszik, hogy objektív mérést végezhessünk, mint ahogy azt a jelen vizsgálatban is láthattuk. 